\title{
Interrelationships between breed, growth hormone genotype, plasma IGF-I level and meat performance in bulls of different ages (short communication)
}

\begin{abstract}
Summary
The aim of our studies was to determine, whether difference in GH alleles affect growth performance in cows, and whether these effects may be mediated by IGF-I. The presence of L (leucine-rich) and V (valine-rich) alleles of GH, plasma IGF-I level and changes in body mass were analyzed in 84 bulls of Simmental (meat) and Holstein (milk) breeds at $90 \mathrm{~d}$ and $180 \mathrm{~d}$ of age using PCR, agarose gel electrophoresis and IRMA. The agedependent increase in body mass, daily gain and plasma IGF-I concentration was observed in Simmental bulls. In Holstein bulls the age-dependent rise in plasma IGF-1 was also found, whilst Holstein bulls had significantly lover IGF-I level, than Simmental bulls. The proportion of LL, VV and LV genotypes of GH in the randomly selected herd of Simmental bulls was $0.25: 0.20: 0.55$. Animals of VV genotype had lower body mass, daily gain and plasma IGF-I level, than bulls of LL and LV genotypes, whilst no differences in these indexes between LL and LV genotypes were found.

The observed association of growth rate, GH genotype and IGF-I level, suggest that GH genotype may affect meat performance via IGF-I secretion.
\end{abstract}

Key Words: GH, gene polymorphism, insulin-like growth factor I, growth, bull

\section{Zusammenfassung}

Titel der Arbeit: Wechselbeziehungen zwischen Rasse, Wachstumshormongenotyp, Plasma IGF-I Niveau und Fleischleistung bei Bullen unterschiedlichen Alters (Kurzmitteilung)

Ziel der Untersuchungen war zu beurteilen, ob die Unterschiede in Wachstumshormon (GH) Allelen das Wachstum bei Kühen beeinflussen können und ob diese GH Effekte durch IGF-I (insulin-like growth factor) beeinflußt werden. Bei 84 Bullen der Rassen Simmentaler (Fleischtyp) und Holstein (Milchtyp) aus verschiedenen Herden der West- und Zentralslovakei wurde mit Hilfe der PCR und Agarose Gel Elektrophorese das Vorhandensein von L (Leucin) und V (Valin) GH-Allelen überpruft. Im Alter von 90 und 180 Tagen wurde das Gewicht der Bullen bestimmt und die Plasma-IGF-I-Konzentration anhand eines IRMA ermittelt. Bei den Simmentaler Bullen wurde ein altersabhangiger Anstieg des Korpergewichtes und der IGF-I beobachtet. Auch bei den Holstein Bullen ergab sich ein altersabhăngiger Anstieg der Plasma-IGF-I Konzentration, wobei die Simmentaler Bullen deutlich höhere IGF-I-Spiegel als die Holstein Bullen aufwiesen. Innerhalb der Simmentaler Bullengruppe, die zufällig ausgewăhlt war, lag das Verhalltnis der LL, VV und LV GH-Genotypen zueinander bei $0,25: 0,20: 0,55$. Die Simmentaler Bullen des Genotyps VV hatten ein geringeres Korpergewicht und niedrigere IGF-I-Spiegel als die Bullen der LL bzw. LV Genotypen. Keine Unterschicde wurden sowohl im Korpergewicht als auch in der IGF-I-Konzentration bei Tieren mit LL und LV Genotypen gefunden. Die nachgewiesenen Beziehungen zwischen Wachstum, GH-Genotypen und IGF-I-Konzentration deuten darauf hin, dass die verschiedenen GH-Genotypen die Fleischproduktion durch IGF-I-Sekretion regulieren. Schlusselwörter: Wachstumshormon (Somatropin), Genpolymorphismus, insulin-like growth factor I,
Wachstum, Bullen

\section{Introduction}

The growth hormone (GH) - insulin-like growth factor I (IGF-I) system plays a key role in control of metabolism, growth and, consequently, animal meat performance 
(BERNEIS and KELLER, 1996; FLORINI et al., 1996). Therefore, study of genetical and physiological regulators of GH and IGF production and action is important from both theoretical and economical viewpoints. In particular, the known differences between bovine Simmental (selected for growth and meat performance) and Holstein (predominantly dairy) breeds in rate of growth and milk performance (MASILO et al., 1992; SNEYERS et al., 1994) may be associated with polymorphism of several GH genes (HALLERMAN et al., 1987; SNEYERS et al., 1994; SABOUR and LIN, 1996). On the other hand, analysis of $\mathrm{GH}$ alleles resulting from the substitution of leucine (L) with valine (V) in position 127 of amino acid residue showed no significant differences in the frequency of $\mathrm{L}$ allele between Holstein cattle (frequency 0.76 according to ZHANG et al., 1993, 0.80 according to SCHLEE et al., 1994a and 0.73 according to CHRENEK et al., 1998) and Simmental breed (0.73 according to ZHANG et al., 1993 and 0.71 according to SCHLEE et al., 1994b). Furthermore, no association of $\mathrm{L}$ and $\mathrm{V}$ alleles with milk performance was found in Simmental bulls (SCHLEE et al., 1994a). Nevertheless, these authors demonstrated the association of L allele with increased meat performance in Simmental bulls (SCHLEE et al., 1994b) and V allele - with enhanced milk production in Holstein cattle (SABOUR and LIN, 1996). Therefore, the association of these alleles with particular bovine breeds and their production traits requires further clearance.

The mechanisms of relationships between $\mathrm{GH}$ alleles and performance are not completely known. GH can exert part of its anabolic effects via stimulation of IGF-I production (BERNEIS and KELLER, 1996; FLORINI et al., 1996). Several authors (ISTASSE et al., 1990; SCHLEE et al.,1994b; YELICH et al., 1996; BARASH et al., 1998) observed, that higher daily body gain in the bulls is associated with higher GH and IGF-I plasma level, although other authors did not observed any correlation between bovine body gain and plasma IGF-I level (HALL et al.,1995) or concentration and affinity of muscle IGF-I receptors (BOGE et al., 1995). Moreover, LEE et al. (1991) failed to find correlation between plasma GH and IGF-I level in the bulls. Milk performance was positively correlated with plasma GH and negatively correllated with plasma IGF-I (LACASSE et al., 1994). The interrelationships between GH and IGF-I may depend even on the breed: SCHLEE et al. (1994b) reported that plasma GH concentration increased along age in Holstein bulls, but decreased in Simmental bulls, whilst in Simmental bulls the age-dependent rise in plasma IGF-I was observed. In both Holstein and Simmental bulls LL genotype was associated with higher plasma GH and lower plasma IGF-I, than animals with LV allele. Thus, although the most publications demonstrates some interrelationships between GH genes, GH, IGF-I and performance, there is no consensus on the effect of breed, genotype, age, meat production and the state of GH/IGF-I system in cattle.

To understand, whether difference in GH alleles affect growth performance in cows, and whether these effects may be mediated by IGF-I, we have study the relationships between GH genotypes, plasma IGF-I level in bulls of Simmental (meat) and Holstein (milk) breeds of different ages. 
Material and Methods

\section{Animals}

A total of 84 bulls of Simmental (Slovak Pied) and Holstein (Black and White) breeds of previous unknown $\mathrm{GH}$ genotypes and performance, originated from various herds of the Western and Central Slovakia were used in experiments. From 70 days of age animals were kept in standard conditions of stable of Research Institute of Animal Production, Nitra. All bulls were fed with the same standard ration (maize silage with $29-31 \%$ of dry matter, alfalfa hay and concentrate). At 90 and 180 days of age Simmental Bulls were weighted, and the blood samples $(5 \mathrm{ml})$ were aspirated by $5-\mathrm{ml}$ syringe from the jugular vein in both Simmental and Holstein bulls, and collected in glas tubes containing $0.1 \mathrm{ml} 4 \%$ sodium citrate. For IGF-I RIA blood plasma was separated by centrifugation at $\mathrm{x} 2000 \mathrm{~g}$ and frozen immediately after collection at 180 C. For DNA analysis a fresh whole blood without cell lysis was used. Simmental bulls were weighted immediately after birth, and at 90 and 180 days of age.

\section{Genotyping}

DNA was isolated from the blood by phenol-chloroform extraction according to ALBARINO and ROMANOWSKI (1994) and analyzed using PCR and agarose gel electrophoresis as described previously (CHRENEK et al., 1998). The PCR mixture $(30 \mu \mathrm{l})$ contained $200 \mu \mathrm{M}$ of dNTP, PCR reaction buffer $(10 \mathrm{mM}$ Tris- $\mathrm{HCl}, \mathrm{pH} 8.3,50$ $\mathrm{mM} \mathrm{KCl}, 0.1 \mathrm{mg} / \mathrm{ml}$ gelatine, $1.5 \mathrm{mM} \mathrm{MgCl} 2,1 \mathrm{U}$ Taq DNA polymerase (all from AGS, Heidelberg, Germany), $0.5 \mu \mathrm{M}$ each of the primers 5'-GCT GCT CCT GAG GGC CCT TCG-3' and 5'-GCG GCG GCA CTT CAT GAC CCT-3' for GH gene (SCHLEE et al., 1994a) and $100 \mathrm{ng}$ isolated DNA in sterile water. After the first denaturation step at $94^{\circ} \mathrm{C}$ for $4 \mathrm{~min}$, samples were amplified in 35 cycles under the following conditions: denaturation at $94^{\circ} \mathrm{C}$ for $20 \mathrm{~s}$, primer annealing at $59^{\circ} \mathrm{C}$ for 20 $\mathrm{s}$ and primer extension at $72^{\circ} \mathrm{C}$ for $20 \mathrm{~s}$ with $5 \mathrm{~min}$ prolongation of the extension step in the last cycle. The PCR products $(15 \mu \mathrm{l})$ were digested with $5 \mathrm{U}$ of AluI (AG/CT from AGS) at $37^{\circ} \mathrm{C}$ for $3 \mathrm{~h}$. The digested DNA was subjected to electrophoresis in $1 \mathrm{x}$ $\mathrm{TBE}$ on $2.5 \%$ agarose gel containing $\mathrm{EtBr}$ (Boehringer Mannheim, Mannheim, Germany) for $1.5 \mathrm{~h}$ at $70 \mathrm{~V}$ and visualized by digital imager.

\section{IGF-I assay}

Concentration of IGF-I in $100 \mu \mathrm{l}$ blood plasma was determined in duplicate with acidethanol extraction by IRMA using commercial kits from DSL (Webster, USA) according to the instruction of manufacturer. Sensitivity of the assay was $0.3 \mathrm{ng} / \mathrm{ml}$, the cross-reactivity of antiserum used was $<0.01 \%$ to IGF-II, insulin, proinsulin and bGH. The intra- and inter-assau coefficients of variation were $<3.4 \%$ and $8.2 \%$ respectively.

\section{Statistical analysis}

Allele frequencies were calculated by simple allele counting. The data were analyzed with the SAS GLM procedure as described previously (CHRENEK et al., 1998). Significant differences in plasma IGF-I concentration between the groups were determined using ANOVA followed by Duncan's multiple range test. 


\section{Results}

From 84 randomly selected Simmental bulls 21 animals (25\%) were bearing LL genotype, whilst in $17(20.2 \%)$ and $46(54.8 \%)$ VV and LV genotypes respectively were determined. Analysis of body mass of Simmental bulls immediately after birth showed no significant initial difference between animals of various GH genotypes: the body mass was $37.2 \pm 4.2,37.4 \pm 3.8$ and $37.3 \pm 3.2 \mathrm{~kg}$ for LL, VV and LV respectively. Later weighting demonstrated the age-dependent increase in body mass and acceleration of growth in all animals studied. The GH allele-dependent differences in body mass and related daily gain were however found: these indexes in bulls related to VV genotypes were lower, than in animals of LL and LV genotypes in both 90 and 180 days of age. No differences in growth rate between bulls of LL and LV genotypes were observed.

Plasma IGF-I concentration was dependent on breed, genotype within the breed and age of animals. In all animals of each breed and genotype plasma IGF-I level was significantly higher at 180 day, than at 90 day of age. Holstein bulls of genotype LV had significant lower IGF-I level, that Simmental bulls of the same genotype. Within one (Simmental) breed the bulls with VV allele had significant lower plasma IGF-I concentration, than animals with LL or LV alleles, whilst no differences between LL and LV bulls in this respect were found at any age (Table).

Table

Effect of breed, GH genotype and age on plasma IGF-I level, body mass and daily gain in the bulls (Einfluß von Rasse, GH-Genotyp und Alter auf den Plasma IGF-I-Spiegel, das Kðrpergewicht und die tăgl. Gewichtszunahme der Bullen)

\begin{tabular}{|c|c|c|c|c|c|c|c|}
\hline \multirow[t]{2}{*}{ Breed } & \multirow{2}{*}{$\begin{array}{l}\text { Geno- } \\
\text { type }\end{array}$} & \multicolumn{2}{|c|}{$\begin{array}{l}\text { Plasma IGF-I concentration } \\
(\mathrm{ng} / \mathrm{ml}) \text { : }\end{array}$} & \multicolumn{2}{|c|}{ Body mass $(\mathrm{kg})$ : } & \multicolumn{2}{|c|}{ Daily gain $\left(\mathrm{g} \times 10^{\wedge} 2\right)$ : } \\
\hline & & 90 days & 180 days & 90 days & 180 days & 90 days & 180 days \\
\hline Simmental & LL & $\begin{array}{c}261+29 \\
(14)\end{array}$ & $\begin{array}{c}444+36 \mathrm{a} \\
(14)\end{array}$ & $\begin{array}{l}97+13 \\
(21)\end{array}$ & $\begin{array}{l}207+28 \mathrm{a} \\
(21)\end{array}$ & $\begin{array}{c}67+13 \\
(21)\end{array}$ & $\begin{array}{l}95+15 \mathrm{a} \\
\text { (21) }\end{array}$ \\
\hline Simmental & VV & $\begin{array}{c}167+30 b \\
(7)\end{array}$ & $\begin{array}{l}415+47 a \\
\text { (7) }\end{array}$ & $\begin{array}{c}85+12 \\
(17)\end{array}$ & $\begin{array}{l}176+27 \text { a } \\
(17)\end{array}$ & $\begin{array}{l}53+12 \\
(17)\end{array}$ & $\begin{array}{l}77+15 \mathrm{a} \\
\text { (17) }\end{array}$ \\
\hline Simmental & LV & $\begin{array}{c}226+26 \\
(48)\end{array}$ & $\begin{array}{c}487+22 a \\
(48)\end{array}$ & $\begin{array}{c}96+13 \\
(46)\end{array}$ & $\begin{array}{c}201+22 a \\
(46)\end{array}$ & $\begin{array}{c}66+13 \\
(46)\end{array}$ & $\begin{array}{l}91+11 \text { a } \\
(46)\end{array}$ \\
\hline Holstein & LV & $\begin{array}{l}181+23 c \\
(7)\end{array}$ & $\begin{array}{l}331+39 \text { ac } \\
\text { (7) }\end{array}$ & & & & \\
\hline
\end{tabular}

Values are means + S.E.M. a - significant differences $(\mathrm{p}<0.05)$ between 90 and 180 days of age (comparison of animals of the same breed and genotype), b - significant differences $(\mathrm{p}<0.05)$ with LL genotype, $c-$ significant differences $(\mathrm{p}<0.05)$ between the breeds (comparison of animals of the same age and genotype)

\section{Discussion}

Proportion of animals with genotypes LL, VV and LV in randomly selected experimental Simmental population consisted on 84 animals was near $1: 1: 2$, i.e. classical Mendelian distribution of these alleles was confirmed. On the other hand, all 7 Holstein bulls possessed LV allele. This observation may reflect the high frequency of $\mathrm{L}$ allele in Holstein bulls, but also ocassional fluctuation in allele frequency in small population. Anyway it was demonstrated, that the majority of population of both 
Simmental and Holstein bulls had heterozygote LV allele. The frequency of $\mathrm{L}$ allele in Simmental breed $(0.79)$ determined in our studies approximately corresponds to that determined previously by other authors (0.73 - ZHANG et al., 1993, 0.71 - SCHLEE et al., 1994b).

Comparison of body mass and daily gain in experimental population suggests that their reduction is associated with presence of VV allele. These data are in agreement with previuous report of SCHLEE et al. (1994b) on association of $L$ allele with increased growth. These observations suggest that GH genotyping may be principally useful for selection of bulls for meat performance.

We observed, that IGF-I level in Simmental bulls (meat breed) had significantly higher plasma IGF-I level, than Holstein bulls (milk breed) of the same genotype. Furthermore, the age-dependent acceleration in growth was associated with higher plasma IGF-I level. The breed- and age-dependent changes in plasma IGF-I level in both Simmental and Holstein bulls observed in our experiments is in agreement with previous observation of SCHLEE et al. (1994b). Furthermore, our data support the reports of ISTASSE et al. (1990), SCHLEE et al. (1994b), YELICH et al. (1996), BARASH et al. (1998) on association of bull body gain with IGF-I plasma level, but they are opposite to data reported by HALL et al. (1995), who did not find such correlation. Thus, our observations, together with reports of other authors, suggest that meat performance may be associated with IGF-I level in general circulation, and that IGF-I may be regulator and indicator of growth rate in bulls.

It was demonstrated that not only age- and breed-, but also genotype-dependent differences in body mass and daily gain are associated with significant differences in plasma IGF-I level: bulls of VV genotype, in comparizon to other genotypes, had reduced both meat production and IGF-I concentration. This is the first report of influence of $\mathrm{GH}$ genotype on growth factor in farm animals. The observed association of GH genotype with plasma IGF-I level suggests, that the effect of GH alleles on bulls growth and meat production may be mediated by IGF-I secretion.

\section{Acknowledgements}

The authors are indebted to Ing. J. Kmet', Dr. D. Vašiček, Ing. T. Gajarská, Mrs. T. Cívaňová, K. Tothová and Ms. M. Kubéková for technical assistance during conduction of these experiments.

\section{References}

ALBARINO, C.G.; ROMANOWSKI, V.:

Phenol extraction revisited: a rapid preservation of human genomic DNA from whole blood. Mol. Cell. Probes 8 (1994), 423-427

BARASH, H.; AHARONI, Y.; BROSH, A.; HOLZER, Z.:

Effect of low energy diets followed by a compensatory diet on body weight gain and plasma hormone concentrations in bull calves. J. Dairy Sci. 81 (1998), 250-254

BERNEIS, K.; KELLER, U.:

Metabolic actions of growth hormone: direct and indirect. Baillieres Clin. Endocrinol. Matab. 10 (1996), 337-352 
BOGE, A.; SAUERWEIN, H.; MEYER, H.H.:

IGF-I and insulin receptors in bovine skeletal muscle: comparisons of different developmental ages, two different genotypes and various individual muscles. Exp. Clin. Endocrinol. Diabetes 103 (1995), 99-104

CHRENEK, P; VAŠICEK, D.; BAUEROVÁ, M.; BULLA, J.:

Simultaneous analysis of bovine growth hormone and prolactin alleles by multiplex PCR and RFLP. Czech J. Anim. Sci. 43 (1998), 53-55

FLORINI, J.R.; EWTON, D.Z.; COOLICAN, S.A.: Growth hormone and insulin-like growth factor systém in myogenesis. Endocr. Rev. 17 (1996), 481-517

HALL, J.B.; STAIGNILLER, R.B.; BELLOWS, R.A.; SHORT, R.E.; MOSELEY, W.M.; BELLOWS, S.E.: Body composition and metabolic profiles associated with puberty in beef heifers. J. Anim. Sci. 73 (1995), 3409-3420

HALLERMAN, E.M.; NAVE, A.; KASHI, Y.; HOLZER, Z.; SOLLER, M.; BECKMANN, J.S.: Restriction fragment lenght polymorphism in dairy and beef cattle at the growth hormone and prolactin loci. Anim. Genet. 18 (1987), 213-222

ISTASSE, L.; VAN EENAEME, C.; EVRARD, P.; GABRIEL, A.; BALDWIN, P.; MAGHUIN-ROGISTER, G.; BIENFAIT, J.M.: Animal performance, plasma hormones and metabolites in Holstein and Belgian Blue growing-fattening bulls. J. Anim. Sci. 68 (1990), 2666-2673

LACASSE, P.; BLOCK, E.; PETITCLERC, D.: Effect of plane of nutrition before and during gestation on the concentration of hormones in dairy heifers. J. Dairy Sci. 77 (1994), 439-445

LEE, C.Y.; HUNT, D.W.; GRAY, S.L.; HENDRICKS, D.M.: Secretory patterns of growth hormone and insulin-like growth factor - I during peripubertal period in intact and castrated male cattle. Domest. Anim. Endocrinol. 8 (1991), 481-489

MASILO, B.S.; STEVENSON, J.S.; SCHALLES, R.R.; SHIRLEY, J.E.: Influence of genotype and yield and composition of milk on interval to first postpartum ovulation in milked beef and dairy cows. J. Anim. Sci. 70 (1992), 379-385

SABOUR, M.P.; LIN, C.Y.:

Association of bovine growth hormone genetic variants with milk production traits in Holstein cattle. Anim. Genet. 27 (Suppl.2) (1996), 105

SCHLEE, P.; GRAML, R.; ROTTMANN, O.; PIRCHNER, F.: Influence of growth hormone genotypes on breeding values in Simmental bulls. J. Anim. Breed. Genet. 111 (1994a), 253-256

SCHLEE, P.; GRAML, R.; SCHALLENBERGER, E.; SCHAMS, D.; ROTTMANN, O.; OLBRICH-

BLUDAU, A.; PIRCHNER, F.: Growth hormone and insulin-like growth factor concentrations in bulls of various growth hormone genotypes. Theor. Appl. Genet. 88 (1994b), 497-500

SNEYERS, M.; RENAVILLE, R.; FALAKI, M.; MASSART, S.; DEVOLDER, A.; BOONEN, F.; MARCHAND, E.; PRANDI, A.; BURNY, A.; PORTETELLE, D.:

TaqI restriction fragment lenght polymorphism for growth hormone in bovine breeds and their association with quantitative traits. Growth Regul. 4 (1994), 108-112

YELICH, J.W.; WETTERMAN, R.P.; MARSTON, T.T.; SPICER, L.J.:

Luteinizing hormone, growth hormone, insulin-like growth factor-I, insulin and metabolites before puberty in heifers fed to gain at two rates. Domest. Anim. Endocrinol. 13 (1996), 325-338

ZHANG, H.M.; BROWN, D.R.; DENISE, S.K.; AX, R.L.: Polymerase chain reaction-restriction fragment length polymorphism analysis in the bovine somatotropine gene. J. Anim. Sci. 71 (1993), 2276

Received: $1999-11-12$

Accepted: $2000-10-10$

Address for correspondence

Dr. ALEXANDER V. SIROTKIN, PhD, DrSc.

Research Institute of Animal Production,

Hlohovská 2

94992 Nitra,

Slovakia

E-Mail: sirotkin@vuzv.sk 